\title{
The Timber Value of an Existing Forest Stand ${ }^{1}$
}

\author{
Andres Susaeta ${ }^{2}$
}

We present in this publication a straightforward and intuitive approach based on compounding costs to determine the timber value of a forest at any stage of its development. This publication targets professional forest managers, tax specialists, and others who work with forest landowners regarding economic valuation of forests.

The land expectation value (LEV) formula of a forest stand (Faustmann 1849) is widely employed in forest appraisal as an indicator of the profitability of a forest investment. It is also an instructive method to determine the optimal rotation age of forest stand, as shown in Susaeta and Demers (2019a). The LEV approach assumes that the forest stand is initially bare of trees. However, there are several situations in which a forest landowner is managing an existing stand and is interested in knowing the value of trees as well as the total value of the forest stand-as shown in Susaeta and Demers (2019b). In the case of the value of the trees, the LEV approach provides an incomplete valuation of the stand because the timber value of an existing stand is not considered. The compounding cost method is a helpful alternative to determine the capital value of the trees.

\section{The Compounding Cost Method}

The underlying assumption of this approach is that the forest landowner of a stand of age $u$ has to be economically compensated for maintaining the stand for $u$ years. The forest landowner not only has to be compensated for the costs incurred in growing the stand, but also for the opportunity cost of using the land for timber production, and for the value of time.
The notion of the opportunity cost of using the land implies that the forest landowner, instead of growing the stand, could annually rent out the land to a forest manager and obtain revenue. On the other hand, the value of time refers to that fact that the forest landowner could reinvest money spent on growing and maintaining the stand and earn interest. The timber value (TV) of an $n$-year-old stand can be determined as follows:

$$
\begin{aligned}
& C_{0}(1+r)^{n} \quad C_{0}=\text { establishment costs } \\
& +\sum_{t=1}^{n} C_{t}(1+r)^{n-t} \quad \begin{array}{l}
C_{t}=\text { the periodical silvicultural costs to grow the } \\
\text { stand at time } t, \text { e.g., fertilization }
\end{array} \\
& T V=\quad+\sum_{t=1}^{n} C_{a t}(1+r)^{n-t} \quad C_{a t}=\text { the annual administration costs at time } t \\
& +\sum_{t=1}^{n} L_{t}(1+r)^{n-t} \quad L_{t}=\text { the annual land rent at time } t
\end{aligned}
$$$$
\begin{array}{ll}
-\sum_{t=1}^{n} A_{t}(1+r)^{n-t} & \begin{array}{l}
A_{t}=\text { the economic timber benefits, e.g., thinnings } \\
r=\text { discount rate; } t \leq n
\end{array}
\end{array}
$$

The equation above indicates that timber value is the sum of the compounded costs from the moment of planting the stand (age 0 years) until stand age $n$ years. It also illustrates that compounded economic benefits of thinnings should be deducted if thinnings have been conducted. It also incorporates the notion of annual land rent $\left(L_{\mathrm{t}}\right)$ as a cost. The annual land rent $L_{\mathrm{t}}$ can be calculated by multiplying the discount rate times the land expectation value ( $L E V)$. The LEV represents the present value of the bare land for growing timber forever. It considers cash flows of costs and timber revenues and assumes a perpetual cycle of clearcut and replant. Assuming $T$ as the rotation age-the time

1. This document is FOR366, one of a series of the School of Forest, Fisheries, and Geomatics Sciences, UF/IFAS Extension. Original publication date March 2021. Visit the EDIS website at https://edis.ifas.ufl.edu for the currently supported version of this publication.

2. Andres Susaeta, assistant research scientist, School of Forest, Fisheries, and Geomatics Sciences; UF/IFAS Extension, Gainesville, FL 32611.

The Institute of Food and Agricultural Sciences (IFAS) is an Equal Opportunity Institution authorized to provide research, educational information and other services

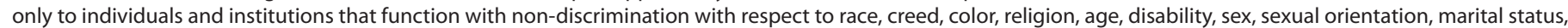

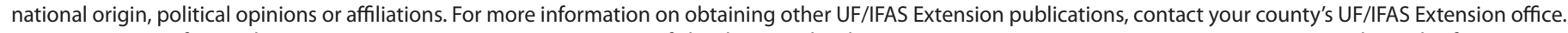
U.S. Department of Agriculture, UF/IFAS Extension Service, University of Florida, IFAS, Florida A \& M University Cooperative Extension Program, and Boards of County Commissioners Cooperating. Nick T. Place, dean for UF/IFAS Extension. 
when the stand is harvested and replanted-the LEV of a forest stand for timber production is as follows:

$L E V=\left(-C_{0}-\sum_{t=1}^{T} \frac{C_{t}}{(1+r)^{t}}-C_{a t}\left[\frac{(1+r)^{T}-1}{r(1+r)^{T}}\right]+\sum_{t=1}^{T} \frac{A_{t}}{(1+r)^{t}}\right) * \frac{(1+r)^{T}}{r(1+r)^{T}}$

In terms of notation, the only difference between the LEV formula and the TV of a stand is that the LEV formula also includes the economic timber benefits due to final harvest.

\section{Example}

The following example illustrates how to determine the existing timber value of a stand. ${ }^{\star}$ Assume a 15 -year-old slash pine stand with the following costs and economic revenues associated with silvicultural activities indicated in Table 1 . The stand is planted at year 0 and harvested at 25 years, and replanting is assumed to happen immediately for the second and subsequent rotations. The activities and associated values described in Table 1 are identical for all future rotations. The discount rate is $5 \%$.

Table 2 shows the determination of the timber value of the 15 -year-old stand by compounding all costs from age 0 to age 15 years.

The last column of Table 2 presents the sum of the compounded costs from year 0 to year 15 . The timber value of the stand is $\$ 2236.30$ per acre, which means that this is the amount needed to compensate the forest landowner for growing and maintaining the slash pine stand for 15 years.

A particular situation occurs when the age of the stand $u$ is the rotation age of the stand $T$; i.e., the stand is ready to be harvested and replanted. Table 3 shows the value of the timber of a 25 -year-old stand.

The sum of compounded costs from ages 0 to 25 years is $\$ 4490$ per acre. Not surprisingly, this is the value of the final harvest at 25 years (Table 1). This represents a particular case when a stand is ready to be harvested from an economic point of view: the stand has reached the age required to derive the maximum timber value. The landowner has to be compensated with an amount equal to the current value of timber when the stand has reached the rotation age.

${ }^{\star}$ The specific details of the silvicultural regime for this example are not relevant. The same methodology can be applied to any forest investment as long as the consistency in timing and value of activities are maintained. See Susaeta and Demers (2019) for a full description of the silvicultural system of slash pine proposed in this study.

\section{Conclusion}

The sum of the compounded costs estimates the timber value of an existing stand, provided that the forest landowner knows the costs of growing and maintaining the stand and the value of the forestland. This approach suggests that the timber value of an immature stand is the economic compensation to be paid to a forest landowner for growing and maintaining the stand. When the forest stand is ready to be harvested, the sum of the compounded cost simply is the value of the final timber benefits realized at the final harvest. The compound cost approach is a useful tool for forest landowners in making an effective and quick timber appraisal and valuing timber investments.

\section{References}

Faustmann, M. 1849. "Calculation of the Value Which Forest Land and Immature Stands Possess.” Reprinted in Journal of Forest Economics 1 (1): 89-114.

Susaeta, A., and C. Demers. 2019a. The Optimal Forest Management of an Even-Aged Stand: The Biological Rotation versus the Land Expectation Value. FOR355. Gainesville: University of Florida Institute of Food and Agricultural Sciences. https://edis.ifas.ufl.edu/fr424

Susaeta, A., and C. Demers. 2019b. What Is the Value of an Existing Forest Stand? FOR354. Gainesville: University of Florida Institute of Food and Agricultural Sciences. https:// edis.ifas.ufl.edu/fr423 
Table 1. Costs and revenues associated with silvicultural activities in a slash pine stand.

\begin{tabular}{|c|c|c|c|}
\hline Year & Activity & Costs & Revenue (\$/acre) \\
\hline 0 & Establishment & 400 & - \\
\hline 5,15 & Fertilization & 70,70 & - \\
\hline 15 & Thinnings & - & 232 \\
\hline $1-25$ & Annual land rent ${ }^{\mathrm{a}}$ & 47.3 & - \\
\hline $1-25$ & Annual administration & 20 & - \\
\hline 25 & Final harvest & - & 4490 \\
\hline \multicolumn{4}{|c|}{$\begin{array}{l}\text { a Annual land rental }=r \times L E V . \\
L E V=-400-70 / 1.05^{5}-70 / 1.05^{15}-20\left(1.05^{5} 1\right) / 0.05\left(1.05^{25}\right)+232 / 1.05^{15}+4990 / 1.05^{25} \\
=\$ 947 \text { per acre } \\
\text { Annual land rent }=0.05 \times 947=47.3\end{array}$} \\
\hline
\end{tabular}

Table 2. Determination of timber value using the compounding cost approach of a 15-year-old stand.

\begin{tabular}{|c|c|c|c|c|c|c|c|c|}
\hline Age & $\begin{array}{c}\text { Silv. } \\
\text { Costs } \\
C_{0^{\prime}} C\end{array}$ & $\begin{array}{c}\text { Thin. } \\
\text { Revenue } \\
A_{t}\end{array}$ & $\begin{array}{c}\text { Adm. } \\
\text { Cost } \\
C_{a t}\end{array}$ & $\begin{array}{c}\text { Land Rent } \\
\qquad t\end{array}$ & $\begin{array}{c}\text { Total Cost } \\
\begin{array}{c}T_{\mathrm{c}}=C_{\mathrm{o}}+C-A \\
+C+L t\end{array}\end{array}$ & \multirow{3}{*}{$\begin{array}{c}\begin{array}{c}\text { Years to } \\
\text { Compound } \\
\boldsymbol{u}-\boldsymbol{t}\end{array} \\
\mathbf{y r} \\
15\end{array}$} & \multirow{3}{*}{$\begin{array}{c}\text { Compound } \\
\text { Factor } \\
(1+r)\end{array}$} & \multirow{3}{*}{$\begin{array}{c}\text { Compound } \\
\text { Cost } \\
T_{c}(1+r) \\
\text { \$acre } \\
831.6\end{array}$} \\
\hline yr & \multicolumn{5}{|c|}{ \$/acre } & & & \\
\hline 0 & 400 & & & & 400.0 & & & \\
\hline 1 & 0 & 0 & 20 & 47.3 & 67.3 & 14 & 2.0 & 133.3 \\
\hline 2 & 0 & 0 & 20 & 47.3 & 67.3 & 13 & 1.9 & 127.0 \\
\hline 3 & 0 & 0 & 20 & 47.3 & 67.3 & 12 & 1.8 & 120.9 \\
\hline 4 & 0 & 0 & 20 & 47.3 & 67.3 & 11 & 1.7 & 115.2 \\
\hline 5 & 70 & 0 & 20 & 47.3 & 137.3 & 10 & 1.6 & 223.7 \\
\hline 6 & 0 & 0 & 20 & 47.3 & 67.3 & 9 & 1.6 & 104.5 \\
\hline 7 & 0 & 0 & 20 & 47.3 & 67.3 & 8 & 1.5 & 99.5 \\
\hline 8 & 0 & 0 & 20 & 47.3 & 67.3 & 7 & 1.4 & 94.7 \\
\hline 9 & 0 & 0 & 20 & 47.3 & 67.3 & 6 & 1.3 & 90.2 \\
\hline 10 & 0 & 0 & 20 & 47.3 & 67.3 & 5 & 1.3 & 85.9 \\
\hline 11 & 0 & 0 & 20 & 47.3 & 67.3 & 4 & 1.2 & 81.8 \\
\hline 12 & 0 & 0 & 20 & 47.3 & 67.3 & 3 & 1.2 & 77.9 \\
\hline 13 & 0 & 0 & 20 & 47.3 & 67.3 & 2 & 1.1 & 74.2 \\
\hline 14 & 0 & 0 & 20 & 47.3 & 67.3 & 1 & 1.1 & 70.7 \\
\hline 15 & 70 & 232 & 20 & 47.3 & -94.9 & 0 & 1.0 & -94.9 \\
\hline & & & & & & & TV (\$/acre) & 2236.3 \\
\hline
\end{tabular}


Table 3. Determination of timber value using the compound cost approach of a 25-year-old stand.

\begin{tabular}{|c|c|c|c|c|c|c|c|c|}
\hline Age & $\begin{array}{l}\text { Silv. } \\
\text { Costs } \\
C_{0^{\prime}}, C\end{array}$ & $\begin{array}{c}\text { Thin. } \\
\text { Revenue } \\
A_{t}\end{array}$ & $\begin{array}{c}\text { Adm. } \\
\text { Cost } \\
C_{a t}\end{array}$ & $\begin{array}{c}\text { Land } \\
\text { Rent } \\
\text { Lt }\end{array}$ & $\begin{array}{c}\text { Total Cost } \\
\begin{array}{c}T_{\mathrm{C}}=C_{\mathrm{o}}+C-A \\
+C+L t\end{array}\end{array}$ & $\begin{array}{c}\begin{array}{c}\text { Years to } \\
\text { Compound } \\
\boldsymbol{u}-\boldsymbol{t}\end{array} \\
\mathbf{y r} \\
25\end{array}$ & \multirow{3}{*}{ 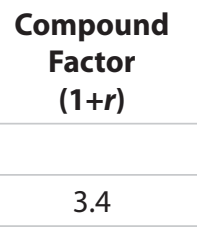 } & $\begin{array}{l}\text { Compound Cost } \\
\qquad \begin{array}{c}\boldsymbol{T}_{\mathrm{C}}(\mathbf{1 + r}) \\
\text { \$/acre } \\
1354.5\end{array}\end{array}$ \\
\hline yr & \multicolumn{5}{|c|}{ \$/acre } & \multirow{2}{*}{\begin{tabular}{|l}
$\mathbf{y r}$ \\
25
\end{tabular}} & & \multirow{2}{*}{$\begin{array}{r}\text { \$/acre } \\
1354.5\end{array}$} \\
\hline 0 & 400 & & & & 400.0 & & & \\
\hline 1 & 0 & 0 & 20 & 47.3 & 67.3 & 24 & 3.2 & 217.2 \\
\hline 2 & 0 & 0 & 20 & 47.3 & 67.3 & 23 & 3.1 & 206.8 \\
\hline 3 & 0 & 0 & 20 & 47.3 & 67.3 & 22 & 2.9 & 197.0 \\
\hline 4 & 0 & 0 & 20 & 47.3 & 67.3 & 21 & 2.8 & 187.6 \\
\hline 5 & 70 & 0 & 20 & 47.3 & 137.3 & 20 & 2.7 & 364.4 \\
\hline 6 & 0 & 0 & 20 & 47.3 & 67.3 & 19 & 2.5 & 170.2 \\
\hline 7 & 0 & 0 & 20 & 47.3 & 67.3 & 18 & 2.4 & 162.1 \\
\hline 8 & 0 & 0 & 20 & 47.3 & 67.3 & 17 & 2.3 & 154.3 \\
\hline 9 & 0 & 0 & 20 & 47.3 & 67.3 & 16 & 2.2 & 147.0 \\
\hline 10 & 0 & 0 & 20 & 47.3 & 67.3 & 15 & 2.1 & 140.0 \\
\hline 11 & 0 & 0 & 20 & 47.3 & 67.3 & 14 & 2.0 & 133.3 \\
\hline 12 & 0 & 0 & 20 & 47.3 & 67.3 & 13 & 1.9 & 127.0 \\
\hline 13 & 0 & 0 & 20 & 47.3 & 67.3 & 12 & 1.8 & 120.9 \\
\hline 14 & 0 & 0 & 20 & 47.3 & 67.3 & 11 & 1.7 & 115.2 \\
\hline 15 & 70 & -232 & 20 & 47.3 & -94.9 & 10 & 1.6 & -154.6 \\
\hline 16 & 0 & 0 & 20 & 47.3 & 67.3 & 9 & 1.6 & 104.5 \\
\hline 17 & 0 & 0 & 20 & 47.3 & 67.3 & 8 & 1.5 & 99.5 \\
\hline 18 & 0 & 0 & 20 & 47.3 & 67.3 & 7 & 1.4 & 94.7 \\
\hline 19 & 0 & 0 & 20 & 47.3 & 67.3 & 6 & 1.3 & 90.2 \\
\hline 20 & 0 & 0 & 20 & 47.3 & 67.3 & 5 & 1.3 & 85.9 \\
\hline 21 & 0 & 0 & 20 & 47.3 & 67.3 & 4 & 1.2 & 81.8 \\
\hline 22 & 0 & 0 & 20 & 47.3 & 67.3 & 3 & 1.2 & 77.9 \\
\hline 23 & 0 & 0 & 20 & 47.3 & 67.3 & 2 & 1.1 & 74.2 \\
\hline 24 & 0 & 0 & 20 & 47.3 & 67.3 & 1 & 1.1 & 70.7 \\
\hline 25 & 0 & 0 & 20 & 47.3 & 67.3 & 0 & 1.0 & 67.3 \\
\hline & & & & & & & TV (\$/acre) & 4490 \\
\hline
\end{tabular}

